\title{
WORKING ON TRANSVERSAL COMPETENCIES OUT OF DOORS
}

\author{
Henrietta, TORKOS, Ph.D. cnd., \\ Aurel Vlaicu University of Arad \\ torkos_henriette@yahoo.com
}

\begin{abstract}
This article has two important aspects of modern education in the spotlight. First, it discusses the need for the development of transversal competencies, as it is required from our modern society. Secondly, it gathers all the modern methods, in which this is possible in schools, mostly considering outdoor education a great way of putting it all into practice. It also gives practical suggestions on how to practically develop transversal competencies through outdoor education, and presents a brief research and its results on the changes that were brought to everyday education, regarding the development of transversal competencies on children aged 6 to 8 years old.
\end{abstract}

Key words: tranversal competencies, skills, outdoor learning, education, method

\section{Introduction}

One of the greatest challenges of contemporary education worldwide is to develop strong individuals, ready to face everyday situations in their personal and social life. Society represents reality, and educational systems should prepare students to be able to face reality. Reality is represented by the demands that the society is lifting up daily, the rapid changes which require fast adaptability, being able to communicate and be understood, the capability to take decisions as fast as it is required, autonomy, team work and so on. Education, as it was before, wasn't able to respond promptly to all these demands, because it was based mostly on transmitting, listening, assimilation and refunding information with all its aspects. It was also based on the teacher and its authority. Students and pupils had a passive role, their activity was mostly based on listening, recording and reproducing everything they heard. A contemporary education, is different, we could even say it is the opposite of the first one. Today, education is based on the pupil, but not 
individually but as part of a group, and mostly on the learning experiences elaborated by teachers but starting from the needs of the group. (Chiş, 2002)

We can also say that from the education of listening, it had developed to the education of activity, and now we are at the interactive pedagogy stage. Being interactive means being curios, researching, searching, experiencing. According to Higgins, (Higgins, Loynes, 1997), a good and qualitative learning based on experience should include the following stages:

- experiencing experience,

- reflection on experience,

- applying new knowledge to new situations

- generalizing the principles so that they can be applied to future situations,

- considering the value of the whole process as learning.

How to put experiential learning into practice and also get the expected results in the development of transversal competencies? Well the answer comes right as outdoor learning activities. There had always been the question on how can educational programs be refreshed? A single person could not be able to respond to that, and even a group of experts would need lots of time to find the optimal solution. (Ilica, 2016)

\section{Theoretical foundation}

A competence is defined as a specific configuration of knowledge, attitude, skill that lead to new behaviors and which allow an individual to perform an action / task given, in a given context, in a particular role and having view specific criteria.

Transversal competences are value acquisitions and attitudes that go beyond a specific field / program of study and are expressed through the following descriptors: autonomy and responsibility, social interaction, personal and professional development.

Transversal competencies, without enumeration being limiting, provide: teamwork skills, oral and written communication skills in native / foreign languages; skills of reasoning and argumentation and critical thinking; the use of information and communication technology - ICT; problem solving and decision making; recognition and respect for diversity and multiculturalism; learning autonomy; initiative and entrepreneurship; opening up to lifelong learning; respecting and developing professional values and ethics; skills to operate in an interdisciplinary manner with methodologies and concepts from the real sciences, social sciences and artistic creation, etc.Key competences are a multifunctional, transferable knowledge, skills and attitudes that all individuals need for personal fulfillment and development, social inclusion and job creation. They must 
have developed at the end of compulsory education and should act as a foundation for learning as part of lifelong learning.

Key competences are learning acquisitions that allow flexible and quick adaptation of the graduate, enabling them to (re) learn a field if the job is on the labor market. If in the past there was enough reading and writing as the basis of learning, these fundamentals are no longer sufficient, as the pace of social development, new technologies, and the globalized economy (including the economic crisis) implies acquiring and deepening skills that until yesterday only the field specialist was interested. Today, these purchases must be taught at the table by graduates - both to ensure the progress of a dynamic society and to personal prosperity (material and spiritual). Key competences are combinations of knowledge, skills and attitudes appropriate to the context. These acquired acquisitions can be transferred to other, more general contexts, but with the basic characteristics of the ones they have formed. They overlap and intersect, and basically the component elements can be reconfigured in the mosaic, being crossed by a number of themes that apply transversely: critical thinking, creativity, problem solving, risk assessment, decision-making, constructive management of emotions.

Human society is constantly changing, so education is required to keep up with the demands of society. Pedagogy should be a forward-looking science able to identify the premises of an innovative learning, to prepare the new generation to deal with new situations, unexpected events. Integrated or modular learning, trans- disciplinarily and new methods based on information techniques, learning for a knowledge society, learning centered on aspirations and aspirations of young people can be topics for this science of education. At the same time, pedagogy must retain its status of science, with persevering care to preserve its core, its terminological coherence, as well as the fundamental science status, capable of theorizing human aspects into the general evolution of the individual, the organizations and humanity (Anton Ilica 2013)

\section{Directions}

Outdoor education usually refers to organized learning that takes place in the outer environment. Outdoor education programs often involve experiences based on wildlife travelers or the near environment where students participate in a variety of challenging adventures and outdoor activities such as hiking, climbing, canoeing, rope racing or games group. The John Muir Award is an organization that encourages and provides opportunities for outdoor education. Outdoor learning is based on the philosophy, theory and practice of experimental education and environmental education. Forest school is an approach to outdoor education 
that supports the development of self-confidence, self-esteem in a natural environment.

There have been some specialists who reacted to the above definition, saying that outdoor learning is based on relationships. Connections in terms of people and those related to natural resources. Julian W. Smith described outdoor education as a learning environment for things that can be learned best outside the classroom (Smith, 1955). Some describe it as a concept that takes into account an entire education program based on the experience and practical activity that takes place outside the classroom in the natural environment. It is based on theory and philosophy, on the practice of experiential education, ecological education and environmental education. It helps people to understand better, understand the world, and especially to gain a better understanding of the people around them. It is considered a modern method of learning, a type of relatively new education, often called experimental education; produces strong educational effects and, as a benefit, it is mentioned especially those involving innovation, leadership, communication and many other aspects of modern life.

The term outdoor education is widely used with reference to a multitude of outdoor activities that take place in a variety of ways, but predominantly outdoor environments or spaces. Common or common definitions of outdoor education are difficult to determine because interpretations vary according to culture, philosophy, or local conditions. Outdoor education is often associated with adventure education, adventure programs, outdoor schooling, adventure therapy, recreation or tourism, expedition learning, challenging education, learning by experience, environmental education, forestry school and wildlife education.

Outdoor education is not time spent outside, as it was once thought, and no relaxation or play, nor does it refers to leisure activities as it is still believed. As its name implies, it is about learning and involves learning activities, it is a way of education, it can often involve residential or travel experiences in which students participate in a variety of adventurous challenges but must have as their primary purpose: learning. The purpose of outdoor education is therefore not external activity but multilateral learning. For example, an educator can learn how to overcome adversity, work with others, develop a deeper relationship with nature, with peers, and with themselves. Some specialists say education for adventures is outdoor education. I would say that it is just a component of outdoor education as well as ecological education. Indeed, it helps to develop interpersonal and intrapersonal relationships, but they do not represent outdoor education, but it complements it. To end all the definitions discussed here, outdoor education is a cultural construction that addresses and applies differently 
from one system to another. It is a type of education for social, personal and environmental development (Higgins, 2002).

\section{Recent perspectives}

Recent research shows that the best way of developing competencies or getting to the expected results in learning is giving maximum freedom in the teaching learning activities. This does not mean that the role of teacher disappears completely, but it gets a hidden role. Teachers prepare and conduct the whole teaching experience, children get involved actively in the whole process and they are the main actors of the process.

Outdoor education can be defined as a learning experience in, for or outside (Donaldson, 1958). This definition describes outdoor education as a form of learning in the natural environment, learning about nature, animals and plants, and nature, which means that we need to think in the future and take care of the resources of our planet. As usual, there have been many reactions to this definition, from education specialists, pedagogues and teachers as well. Many have said that outdoor education and many of its aspects can be done indoors as well. There can be many activities that do not require an outdoor environment. Others, on the other hand, say that the learning process can not only be about the outdoor environment. Socialization and personal involvement could be as important as the environmental aspect. However, previous studies show that socialization can be made easier in an open, free, constrained environment. Learning situations are also important. There are some experts who believe that the main purpose of outdoor learning should be independent learning, free thinking and independent problem solving. The aforementioned definition was a solid basis for considering learning outwardly a new learning method (Priest, 1990).

\section{Study case}

For example, a research has been done on a number of 80 pupils, aged 6 to 8. They were selected from different schools, some of them belonging to schools from different countries, Hungary and Romania. They were all monolingual; they only spoke Romanian and Hungarian, depending on the school they came from. There was a workshop organized, for three consecutive days, were pupils were directly involved in outdoor learning activities. Each day, pupils had to participate into four different workshop activities. After each day, Hungarian pupils went back to their countries, according to the fact that they lived close to the border.

The outdoor learning program was developed by a teacher who has outdoor learning competencies. Some university students, after long meetings and preparations, helped with the good practice of the activity. 
The program, in which these pupils were included, started with the observation of their behavior for several days in different moments of a day, both inside the classroom, during teaching learning activities and even in brakes. The research process started from the hypothesis that if some outdoor learning activities were introduced in their daily activity, there will be positive progress in their behavior, regarding the development of the transversal competencies. There were 2 variables included. First, the independent one, which was the use of outdoor learning activities included in the outdoor workshops. The second one was the dependent variable, the behavioral changes, the development of some transversal competencies. The main instrument used to gradually check the results was the observation. There were phases of observation during outdoor activities, and after workshops, in the classroom. The last phase of observation was in the classroom, where behavior of pupils was observed, mostly competencies such as: collaboration, self-discipline, resourcefulness, and respect for the environment. These competencies are also encompassing skills, values, and attitudes required for the holistic development of learners.

\section{Intervention}

The intervention program contained an intensive three day activity based on outdoor workshops. These workshops were developed in order to test if transversal competences can be developed, but also in order to maintain and develop inter cultural relationships between pupil from different countries, in this case, Hungary and Romania. The 6 to 8 years old pupil participated to 4 different workshops per day, totally a number of 12 controlled outdoor activities. Besides these, pupils had time to experience, to play, to visit around the city. There were activities developed from all areas and subjects, meaning that pupils had real interdisciplinary, holistic learning experiences.

For example, subjects involving math, developed critical thinking and decisional competences. Pupils had to stay in a row, one behind the other, and to run 500 meters where there was a supervisor with a mathematical exercise. Pupils had to listen carefully to the operation, decide on the result, and from a batch of different posters containing numbers, they had to choose the one containing the correct answer. Physical competencies were also developed and fresh air and spending time out of doors, helped a lot in thinking and solving all these simple but so handful exercises.

There were also activities involving arts and communication, which helped pupils develop healthy relationship with one another. For example, pupils were required to collect wild fruits and branches, also grass and different herbs, which they later on used to paint $n$ groups on a given theme. 
There were physical activities too where pupils got into a sack, jumped for 300 meters, took a balloon, popped it, took out a paper containing a question, went back to the group, answered the question, switched places and the next pupil went on track. This learning activity continued until one of the group finished the race first. Questions from the balloons were from all areas and were proper for the ages involved.

Orienteering activities developed autonomy and independent thinking, also experiencing and learning in new areas, and discovering new places in a controlled environment. Orienteering in the city was a great activity of discovering new places and learning to rely on a map and ask for directions. The use of city room is a great way to integrate outdoor activities in the weekly teaching learning program of children. All these activities served to develop new competencies and new relationships between students.

\section{Analyses of the results}

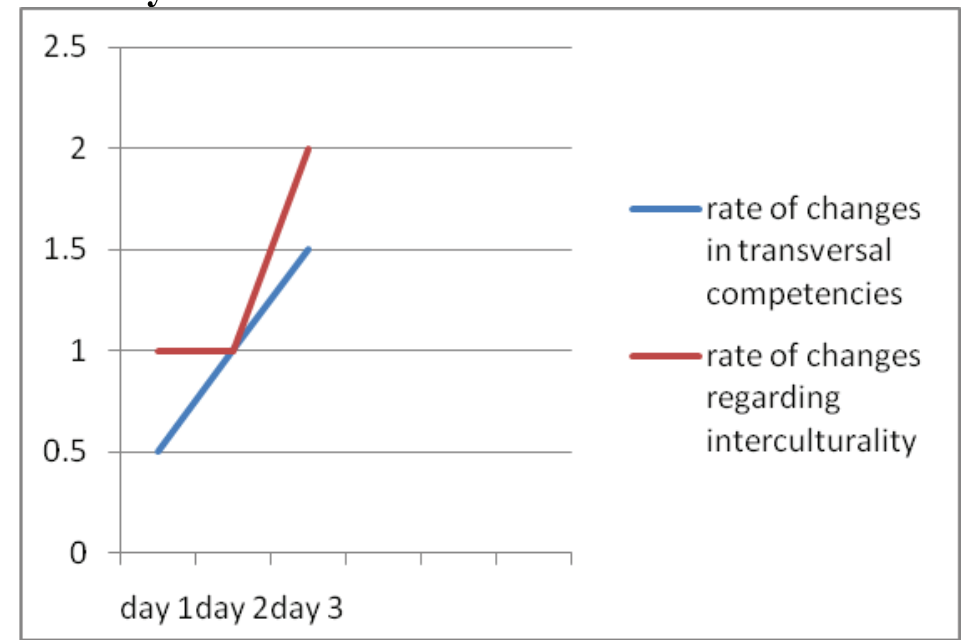

Table1. Rate of changes regarding transversal competencies and intercultural features within the group

There are visible raises in the level of group cohesion, even if on the first and second day, intercultural levels remained the same. There are visible signs that children need a time, even if it is short, to develop communication and friendships, to cooperate in order to resolve problems.

Within classes following this outdoor education program, feedback from teachers hasn't delayed to appear. In the following two weeks students continuously talked about their experience demanding similar actions in their own schools. Group cohesion grew, and follow-up lessons showed willingness to cooperate and communicate, to share and to be opened to new situations. It was noticed that pupils from both countries became opened to try to learn the same contents in different contexts. 


\section{Conclusions}

The more and more enhanced preoccupations for permanent education determines an extension of teaching learning methods, lifelong available. This thing prefigures the placement of non-formal education on new, higher positions. Based on the world wide educational crisis, the whole educational system needs refreshment. School is not the only place where you can learn and activities besides formal educational system come to help out people who desire to learn and to permanently form themselves. Until not a long time ago formal and non-formal education completed each other regarding objectives, contain and organizational ways when today nonformal educational activities are worth of getting degrees such as formal ones. The main role of every educational activity, developed in school or outside of it, represents a pedagogical intentionality (Ionescu, 2005) and it expresses all political and educational orientations regarding the development of human personality according to social and cultural values of the society with the purpose of completely integrating in the social life but most of all in order to develop a useful activity in the social, economic area. (Kelemen, 2014)

Enriching the educational area with activities that develop transversal competences is a must have of the $21^{\text {st }}$ century. If this can be reached in a pleasant way, such as outdoor learning then why not open our doors and let children explore and grow as naturally as possible?

\section{References}

Chiş, V., (2002), Provocările pedagogiei contemporane, Presa Universitară Clujeană

Donaldson, g., AND Donaldson, L., E.,(1958), Outdoor Education: A Definition, Journal of Health, Phisycal Education and Recreation

Higgins, P., Loynes, C.,(1997), Towards consensus on the nature of outdoor education, JAEOL, 13 (4), 2-3

Higgins, P., Nicol R., (2002), Outdoor Education: Authentic Learning in the context of Landscapes, Vol II, Sweden

Ilica, A., (2013), Discurs pedagogic contemporan, Editura Chișinău, Moldova, Învățătorul modern

Ilica, A., (2016), Contra direcției de astăzi în educația românească - opinii şi eseuri pedagogice -, Editura Tiparniţa, Arad

Ionescu, M., (2005), Instrucție şi educație, Editura University Press, Arad

Kelemen, G., (2014), Metodica activităților culturale, civice și recreative, Editura Universității "Aurel Vlaicu", Arad

Priest, S., (1990), The semantics of adventure education, In J. C. Miles \& S. Priest, Adventure Education.

Smith, J., (1955), Outdoor education and youth, Washington, DC: AAHPER 